\title{
BUSINESS MODEL INNOVATION APPROACHES: A SYSTEMATIC LITERATURE REVIEW
}

\author{
Michael Lang ${ }^{1}$ \\ ${ }^{1}$ Department of Management, Faculty of Business and Economics, Mendel University in Brno, Zemědělská 1,
61300 Brno, Czech Republic
}

Link to this article: https://doi.org/10.11118/actaun202068020435

Received: 26. 2. 2020, Accepted: 23. 3. 2020

To cite this article: LANG MICHAEL. 2020. Business Model Innovation Approaches: A Systematic Literature Review. Acta Universitatis Agriculturae et Silviculturae Mendelianae Brunensis, 68(2): 435-449.

\begin{abstract}
The goal of this paper is to evaluate the current academic approaches in the field of business model innovation. By conducting a systematic literature review, 31 academic approaches are identified and compared using the dimensions of business model and process model. In addition, the research concentrates on organizational mindset and to what extend it is considered in current approaches. Among other findings, the research proves that all analyzed studies vary in terms of focus, level of detail and content in the perspectives of business and process model. In particular, organizational mindset is mentioned in four out of the 31 studies as an important success factor of business model innovation, whereas only one approach is dealing with organizational mindset in its process model. This indicates that overcoming the organizational mindset as a main barrier in business model innovation is not systematically integrated in any of the selected studies.

In summary, the findings of this paper highlight that the current research in the field of business model innovation is not sufficient and further research has to follow. Thus, three research gaps are identified. First, the lack of level of detail concerning business and process model. Secondly, the lack of business innovation approaches for specific industries. Finally, the lack of systematic integration of organizational mindset in business model innovation approaches.
\end{abstract}

Keywords: business systematic literature review, strategy, business model, business innovation, organizational mindset, dominant logic

\section{INTRODUCTION}

"You never change things by fighting the existing reality. To change something, build a new model that makes the existing model obsolete." (R. Buckminster Fuller, 1895-1983).

In today's digital world, many companies struggle to achieve their growth and innovation targets (Sniukas et al., 2016, p. 5). One reason is that incumbent companies are confronted with new market players which handle the challenges of a volatile, uncertain, complex, and ambiguous world (VUCA World) more successfully (Bennett and Lemoine, 2017).
For instance, since AirBnB was founded in 2008, the recently 31 billion USD valued company has challenged the hotel sector to an unknown extent (Bensinger, 2017). A decline of $18.6 \%$ of revenue/ room year-over-year in major American cities, like New York, is ascribed to AirBnB (Zervas et al., 2016). There are other examples like Uber, a 50 billion USD valued company with operations in over 50 countries (Sherman, 2017). Uber is challenging the taxi industry through its simple technologyenabled business model. Spotify puts the music industry under pressure with its streaming offerings and Netflix replaced Blockbuster (Matzler et al., 2016, pp. 76-77). 
These challengers are called disruptors, who face incumbent markets with entirely new business models. Until today, businesses of incumbents are threatened significantly even to the point of total destruction (Matzler et al., 2016, p. 13; Rogers, 2016, p. 77). In all of these cases, new business models took over the old ones rapidly. The disruptors succeed in developing new business models and mindsets, which consider the mega-trends such as new technologies, changing customer demands and shortened product cycles. No industry remains unaffected by these disruptive threats (Csik, 2014, p. 1).

In contrast to that, incumbent corporates are still facing the new "VUCA world" (Volatility, Uncertainty, Complexity, Ambiguity) with traditional strategic management approaches of choosing an industry and product market combination (Sniukas et al., 2016, p. 5). This leads to a competitive advantage focusing either on cost leadership, differentiate offerings or on a niche (Porter, 1985). In practice, popular examples of former market leaders like Polaroid or Kodak show how companies struggle or collapse when applying these traditional frameworks (Sniukas et al., 2016, p. 5). Polaroid, the former global leader in the field of instant photography, recognized, as one of the first, the trend towards digital photography, however failed to translate this into an innovative business model (Tripsas and Gavetti, 2000). Kodak, whose bankruptcy became known in 2012, did not manage to break away with its beliefs of the film business, even it held all relevant patents for the digital camera (Gavetti, 2012, p. 81).

Disruption is breaking up the balance of power and existing industry structures and smashes predominant industry mindsets (Rogers, 2016, pp.1-18). A Forbes survey of 400 top global executives reveals $70 \%$ of survey respondents say they are extremely concerned whether their company will still be competitive in two years. But how can incumbents deal with these upcoming disruptive threats? John Chambers, executive chairman and former CEO of Cisco declares the maxim of today's competitive environment (Holmes, 2017): "Disrupt, or you will get disrupted".

According to Rogers (2016, pp.1-18), Sniukas et al. (2016, p. 5) and Wördenweber (2012, p.12), there is a lack of understanding to what extend the companies mindset affects how an organization deals with business model innovation. In contrast to that, Franke and Zu Knyphausen-Aufsess (2014, p. 35) and Bettis and Prahalad (1995, p. 7) point out that there is evidence that overcoming the company's present culture is a major challenge in business model innovation especially in the new VUCA world. For this reason, the research goal is to evaluate to what extend current business model innovation approaches cover the need of integrating the organizations mindset in their strategies. More precisely, the following questions shall be answered through a systematic literature review:
1. What is the current research status on business model innovation approaches?

2. What are the characteristics of the business model innovation approaches in respect to the dimensions of business model and process model?

3. How is organizational mindset represented in the different approaches?

\section{MATERIALS AND METHODS}

\section{Defining Business Model, Business Model Innovation and Dominant Logic}

This section covers the theoretical basis in form of definitions, business model, business model innovation theory itself as well as the current research state of organizational mindset.

\section{Business Model}

At the moment, there is no commonly accepted definition for the term business model (Johnson et al., 2008, p.60). Amit and Zott (2001, p.493) describe a business model as the design of the content of a transaction, the structure and management with the aim of creating value through the use of business opportunities. The use of business opportunities is achieved by the combination of elements. Hamel (2001, p. 10) presents four elements of business models: the customer interface, the main strategy, the strategic resources and the value network (consisting of partners and suppliers). Moreover, Hamel (2001, p.10) integrates three further elements, which connect the previously mentioned elements to one another: the customer, the configuration of activities and the company boundaries. This definition focuses on business model elements and their linking. Hawkins (2002, p. 308) defines a business model as a description of how a company aligns resources, capabilities and processes in order to evolve its full potential for beneficial product or service generation. Johnson et al. (2008, p. 60) see in a business model the compilation of elements that create value. Magretta (2002, p. 4) defines it as the customer, the value for the customer and how customer value can be provided at a reasonable price. Mitchel and Coles (2003, p.17) define a business model as a combination of elements for offering products and services and to develop resources. Osterwalder and Pigneur (2010, p. 14) define a business model as a characterization of how an organization creates value, offers and secures it. Rappa (2004) sees in a business model a description of what a company is doing for generating value, how a company is placed within the value chain and how it manages the collaboration with customers to achieve revenue (2004, p. 34). Similar to Osterwalder and Pigneur, Skarzynski and Gibson (2008, p. 112) understand a business model as 

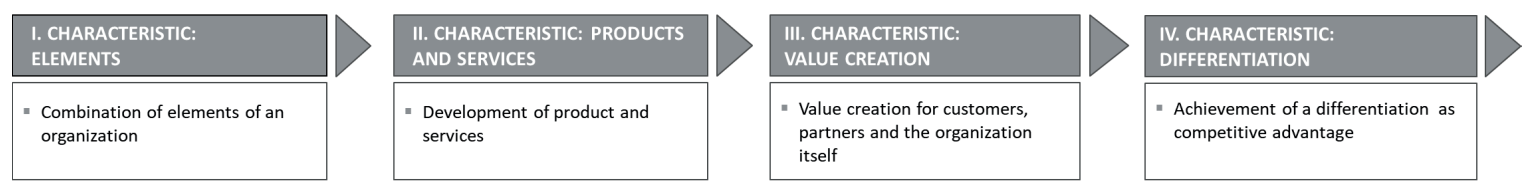

1: Characteristics of business model definitions

2: The four steps of business model innovation (Schallmo, 2013, p. 109)

a framework how a corporation creates, delivers and secures values for itself.

The relevant characteristics of the presented business model definitions are illustrated in Fig. 1.

- Combination of Elements: The combination of elements is an essential component within the definition of business models (Johnson et al., 2008, p. 60; Mitchel and Coles, 2003, p. 17). Other authors use the terms components instead (Hamel, 2001, p. 10) or objects and concepts (Amit and Zott, 2001, p.493; Hawkins, 2002, p.308; Magretta, 2002, p.4; Osterwalder and Pigneur, 2010, p. 14; Rappa, 2004, p. 34).

- Products and Services: The primary function of the combination of elements is the development of products and services (Mitchel and Coles, 2003, p.17; Hawkins, 2002, p. 308).

- Value Creation: The main purpose is to create and deliver value and respectively secure it (Amit and Zott, 2001, p. 493; Johnson et al., 2008, p. 60; Magretta, 2002, p. 4; Osterwalder and Pigneur, 2010, p. 14; Rappa, 2004, p. 34).

- Differentiation and Competitive Advantage: The created values serve to establish customer relationships and to support differentiation against competitors (Lindgardt et al., 2009, p. 3) or to secure a competitive advantage (Mitchel and Coles, 2003, p. 17).

\section{Business Model Innovation}

No common definition for the term business model innovation is present. Johnson (2010, p. 13) defines business model innovation as the ability of the organization to change as a whole. The author (2010, p.144) further understands business model innovation as a prescriptive iterative process. Thus this definition represents the procedural view of the concept of innovation. Lindgardt et al. (2009, p.2) define that innovation becomes business model innovation as soon as two or more elements of a business model are refined in order to add value in a new way. Furthermore, business model innovations are combinations and thus not as easy to imitate as product or process innovations. Mitchel and Coles (2003, p. 17) understand business model innovation as providing new products and services to customers. The authors see the development of such products and services also as a process with the goal of differentiating themselves from competitors. Osterwalder and Pigneur (2010, p. 136) as well as Skarzynski and Gibson (2008, p.111) define that business model innovation is about creating new mechanisms of value generation by focusing on satisfying new or hidden customer needs. Finally, Steenkamp and van der Walt (2004, p.4) note that business model innovation focuses on value creation by customer-orientation.

For this paper, business model innovation describes a process that completely renews a business model or recombines at least two elements of it. In order to create and deliver a value proposition in a way that the customer considers new and innovative to a certain degree. Mitchel and Coles (2003, p. 17).

Fig. 2 shows the four generally accepted steps of business model innovation (Schallmo, 2013, pp. 48-109).

\section{Organizational Mindset}

Organizational mindset is covered by the definition of the term dominant logic in detail. Dominant logic is the prevailing thinking and behavioral pattern of decision makers in an organization based on experience. It contains key assumptions about its identity and is the basis of important decisionmaking (Bettis and Prahalad, 1986).

Dominant logic includes the following dimensions and elements:

- Level of Application: Dominant logic prevails in the entire organization (Bettis and Prahalad, 1986).

- Underlying Theory: Dominant logic has its roots in cognitive psychology (Bettis, 2000).

- Elements: Dominant logic combines behavioral and cognitive elements (Bettis, 2000).

The objective of the dominant logic is to describe the dominant way how decision makers in organizations think and act (Bettis, Wong and Blettner, 2011, p. 351).

\section{The Role of the Dominant Logic within an Organization}

According to Franke and Zu Knyphausen-Aufsess (2014, p.36), an organization's dominant logic is determined by the specification and configuration of internal and external antecedents. Internal antecedents refer to the organization itself, its 


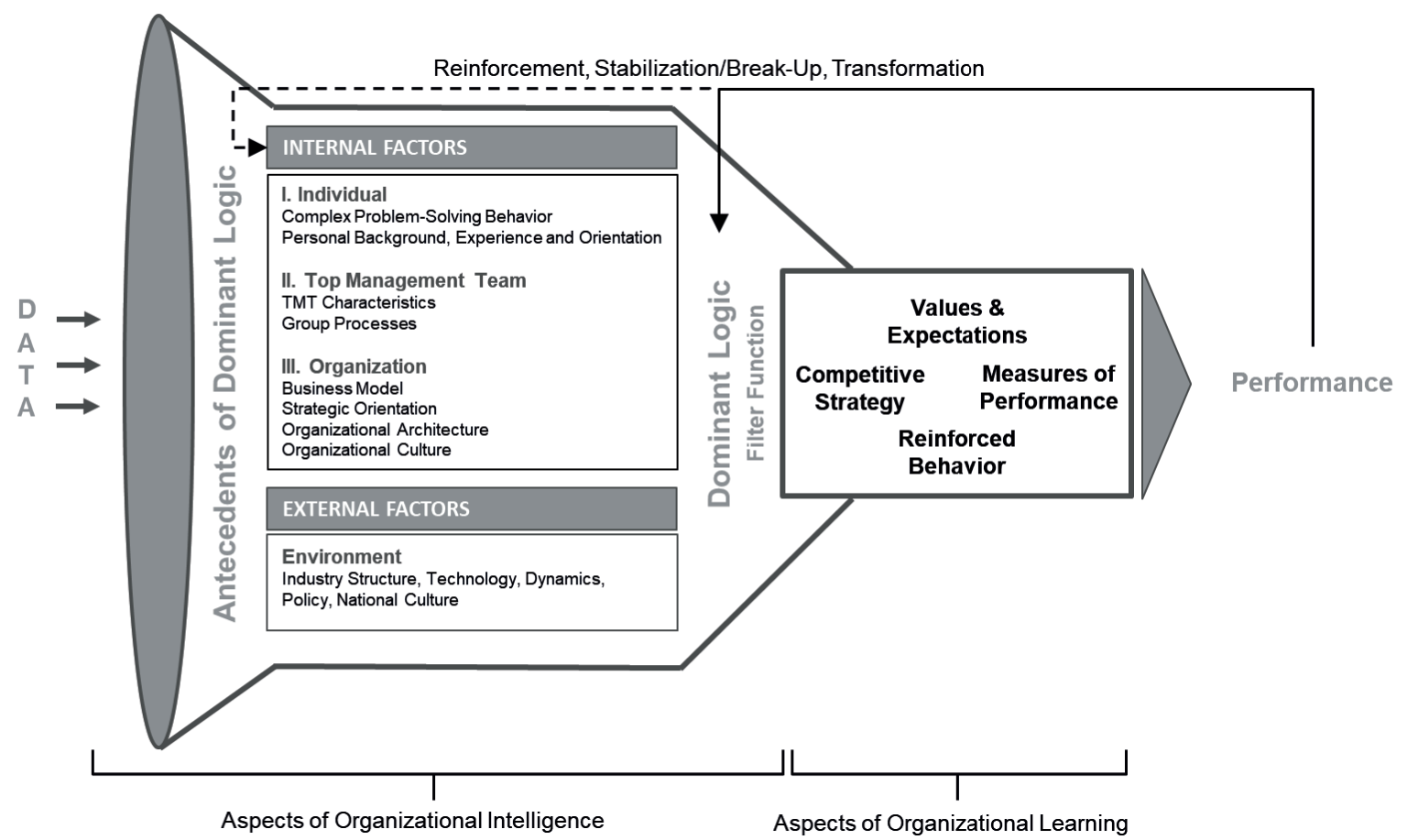

3: Antecedents and function of dominant logic (Franke and Zu Knyphausen-Aufsess, 2014, p. 35; Bettis and Prahalad, 1995, p. 7)

members and elements. Franke and Zu KnyphausenAufsess (2014, p. 36) assign them to an individual, top-management team and organizational level. External antecedents are predetermined by an organization's environment and are thus mostly immutable by the organization. Dominant logic evolves when the internal antecedents fit the organization's environment in a way that enables a company to obtain a successful performance. Fig. 3 elaborates the antecedents, as well as the function and reinforcement of dominant logic.

Fig. 3 also illustrates the filter function of dominant logic. Based on the fit between internal and external antecedents, dominant logic filters relevant data and directs an organization's attention to it. The filtered data is then incorporated into a strategy, values, expectations, performance measures and reinforced behavior of an organization (Bettis and Prahalad, 1995, p. 7). These determine an organization's performance. This illustrates that dominant logic presents an aspect of organizational intelligence, from which organizational learning can emerge. Organizational learning then again shapes the organizational intelligence through feedback loops. The dominant logic itself, as well as its internal antecedents are reinforced through a successful performance (Bettis and Prahalad, 1995, p.7). In managerial practice, this reinforces the consistency of decisions made in the organization (Csik, 2014, p.38). Antecedents, such as established structures, procedures, systems, routines and processes, embody the dominant logic and direct the attention of managers to issues that are deemed important by it. Furthermore, dominant logic provides information, values and decision rules, which standardize and simplify the decision-making process for managers and employees throughout the organization (Bettis, Wong and Blettner, 2011, pp.372-373). Consequently, as long as there is no significant change in the environment (and thus no need to adapt the internal antecedents), dominant logic "can provide a highly effective and efficient means of managing the organization", reduce complexity, enhance consistency and thereby foster the overall stability of an organization (Bettis, Wong and Blettner, 2011, pp. 372-373).

In the long term though, dominant logic consistently increases the homogeneity of the organization and, at the same time, its inflexibility, inefficiency, inadaptability and inability to innovate (Wördenweber, Eggert and Schmitt, 2012, pp.5051, 60). Hence, when a significant change in the environment occurs, inflexible internal antecedents present a major obstacle. (Bettis, Wong and Blettner, 2011, p.373; Csik, 2014, p.38; Bouchikhi and Kimberly, 2003). For example, the tools that managers use to make strategic decisions in congruence with the dominant logic are built on learnings and an environment of the past.

As the environment changes, they will no longer be applicable (Bettis, Wong and Blettner, 2011, p. 373; Bettis and Prahalad, 2000, pp. 126-127, 130). This forces managers and employees to rethink and unlearn, which means adapting or eliminating elements of internal antecedents to make room for new mental maps (Bettis and Prahalad, 2000, pp.130, 136). Especially in high-velocity environments an organization's ability to identify 
and react to external changes depends on the topmanagement's ability to continuously evaluate the fit between the organization's dominant logic and its environment, as well as their willingness to modify or completely unlearn it if necessary (Franke and Zu Knyphausen-Aufsess, 2014, pp. 46, 52). This implies that if a change of the external antecedents destroys this fit, a reconfiguration of the internal antecedents is needed to achieve a new fit between an organization's set of choices and its environment (Franke and Zu Knyphausen-Aufsess, 2014, p. 52).

\section{The Influence of Dominant Logic on Business Model Innovation}

As elaborated in the previous chapter, the dominant logic can particularly impede an organization's ability to innovate by filtering and restricting the management's perception, awareness and understanding of the inter- and intra-organizational context. Aspects not deemed important by the dominant logic are mostly ignored. Consequently, information that possibly indicate a change of the environment and therefore a need for the company to adapt and innovate itself may not reach the relevant decision-making processes (Csik, 2014, pp. 38-39; Tikkanen et al., 2005, p. 792; Hacklin and Wallnöfer, 2012, p. 170).

Additionally to the elaborated definition, Tikkanen et al. (2005, p. 790) conceptualize a business model not only as a "sum of material, objectively existing in structures and processes" but also as "cognitive meaning structures at the level of a business organization”. This highlights that the dominant logic of a company is not only strongly interlinked with the business model but even drives the tendency to avoid business model revision and thus 'protects' the existing business model (Bouchikhi and Kimberly, 2003; Csik, 2014, p. 39; Cavalcante, Kesting and Ulhoi, 2011, p.1328). Tikkanen et al. (2005, p. 791) specify that "in practice, the cognitive aspects of the business model are firstly constituted by the meanings and meaning structures that actors maintain about the components of the business model. Second, the cognitive aspects also relate to the way in which actors perceive the functioning of the business model”. This implicates that a strongly anchored dominant logic can constrain a company's strategic options to an extent that it is not able to cope with a changing environment (Bouchikhi and Kimberly, 2003). Cavalcante, Kesting and Ulhoi (2011, p. 1328) point out that "managers might fail to recognize, explore, seize and exploit valuable new technological and/or market opportunities, since they are not consistent with the present business model”.

Regarding these statements, it can be implicated that a firm's dominant logic can significantly influence the business model innovation process. In particular, these findings imply that dominant

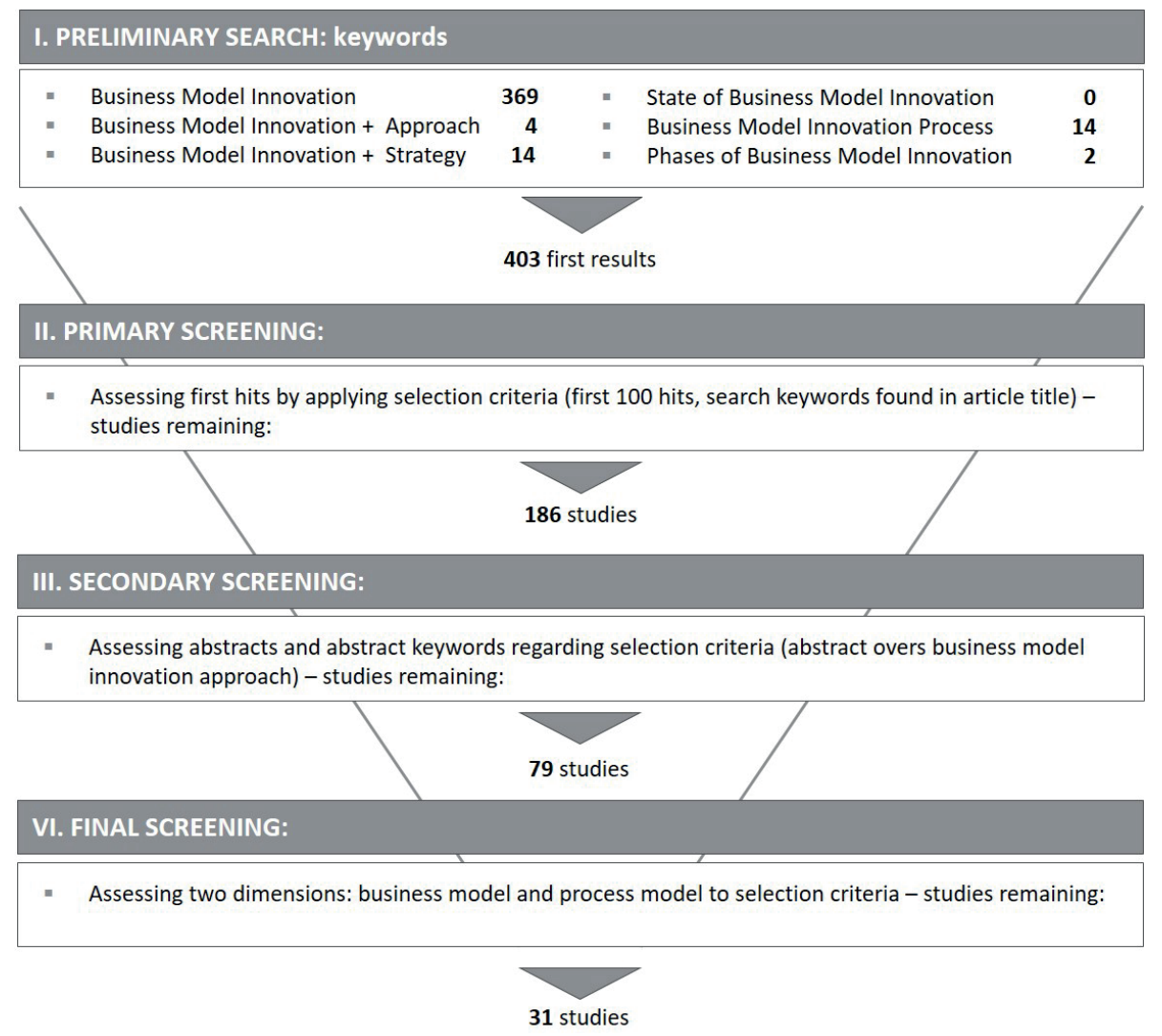

4: Overview of research strategy and results 
logic impedes a comprehensive analysis of the company and its eco-system for potential levers of disruption, as well as an organization's ability to exploit them by creating new business model ideas. Tovstiga and Birchall (2014, pp. 1-2) confirm this assumption by stating that "managers of incumbent companies typically fail to recognize disruptions as opportunities because the potential new markets lie outside their existing resource base" and further that dominant logic prevents them from "recognizing the developing market for the threat that it really poses to them".

\section{Research Strategy}

The research strategy is covered in a research funnel, which is composed of four phases. The first phase is a preliminary research with the goal of identifying valid research papers through a keyword search. The results are assessed in the primary screening by applying selection criteria (Tab. II). The secondary screening evaluates if the present studies cover a business model innovation approach by screening the abstracts. In the final screening, the identified approaches are selected if they contain the dimensions "business model" and "process model" (see Fig. 4).

In the preliminary research, a keyword search is conducted using Google Scholar and BASE (Bielefeld Academic Search Engine) to identify publications in business model innovation. Google Scholar searches all kinds of scientific texts. In reference to OrdunaMalea et al. (2015, pp. 931-949) about 160 million titles are listed and about 50\% of the titles in Google Scholar are freely accessible (Open Access). BASE

I: First results of preliminary research

\begin{tabular}{lc}
\hline \multicolumn{1}{c}{ Search Keywords } & First results \\
\hline Business Model lnnovation & 369 \\
Business Model lnnovation + Approach & 18 \\
Business Model lnnovation + Strategy & 7 \\
State of Business Model lnnovation & 0 \\
Business Model lnnovation Process & 7 \\
Phases of Business Model lnnovation & 2 \\
\hline IN TOTAL & 403 \\
\hline
\end{tabular}

II: Research process documentation

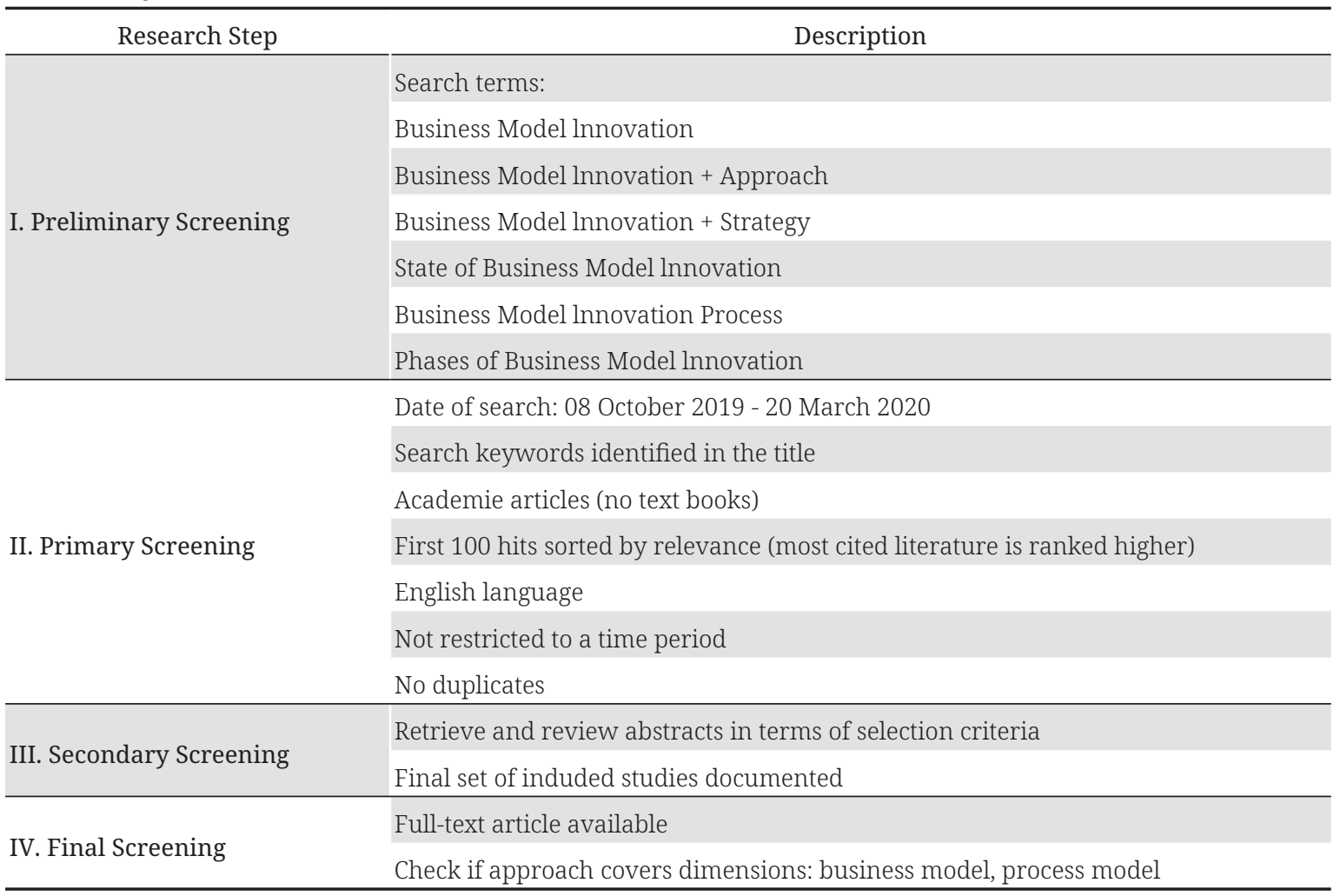


is one of the world's largest search engines for academic web documents. The index comprises more than 150 million documents from over 7,000 sources. About $60 \%$ of the documents listed in BASE are also openly accessible. BASE is used in addition to Google Scholar due to its extended search option, which offers several parameters for the detailed search within publications. The keywords (Tab. I) are used to identify a first set of studies dealing mainly with the topic business model innovation. Overall, the preliminary research generates 403 first results (Tab. I).

The next three screening phases analyze the results of the 403 first results to extract the current business model innovation approaches which fulfill all selection criteria. In the primary screening, the 403 results are filtered continuously. Only the first 100 results per search keyword (most cited literature is ranked higher) in English language will be further evaluated (Tab. II). This leads to 186 studies. The secondary screening focuses on the abstract of articles, given by further research databases (ResearchGate, IEEE Xplore Digital Library, ScienceDirect, Emerald, Wiley.com). The articles shall deal with a concrete concept for business model innovation. This leads to a further reduction to 79 studies. The final screening focuses only on the studies which cover the two research dimensions business model and process model. Finally, 31 studies fulfill the set of criteria and are suitable for further comparison in the next chapter.

\section{Comparison Analysis of Studies ( $\mathbf{n}=31)$}

The 31 identified studies are evaluated according to their common characteristics and differences. At first, the studies are clustered in accordance to their publishing date. Afterwards characteristics of the studies are evaluated in four steps. In the first step, the studies are grouped according to the application fields business strategy, business innovation and information management. The grouping also considers if a study has a special focus such as business transformation, digitalization or sustainability. Next, the described business models are further investigated concerning the mentioned elements within each study. This leads to a final generation of a common set of business model elements. In the third step, analog to the business models, the considered process steps within every study are analyzed to identify a common set of process steps. Finally, all studies are investigated if and how the organizational mindset is covered. Tab. III summarizes the main criteria for comparison.

\section{RESULTS}

\section{Descriptive Results of Studies $(n=31)$}

The first research is focused on academic articles in English language covering the keyword "business model" in the title. This leads to a first result of 2,949 articles. As the amount of results the research strategy is adapted addressing English articles containing "business model innovation” in

III: Applied criteria for comparison analysis of studies

\begin{tabular}{|c|c|c|c|c|}
\hline Study & Focus of Approach & Business Model & Process Model & Organizational Mindset \\
\hline - Author & $\begin{array}{l}\text { - Business } \\
\text { Strategy }\end{array}$ & $\begin{array}{l}\text { - Business model } \\
\text { dimensions and elements }\end{array}$ & $\begin{array}{l}\text { - Amount of considered } \\
\text { steps of selected studies }\end{array}$ & $\begin{array}{l}\text { - Organizational mindset } \\
\text { covered by study } \\
\text { (not, partly, full) }\end{array}$ \\
\hline $\begin{array}{l}\text { - } \text { Year of } \\
\text { publication }\end{array}$ & $\begin{array}{l}\text { - Business } \\
\text { Innovation }\end{array}$ & $\begin{array}{l}\text { - Amount of business } \\
\text { model elements per study }\end{array}$ & $\begin{array}{l}\text { - Distribution } \\
\text { of considered steps } \\
\text { of selected studies }\end{array}$ & \\
\hline - Journal & $\begin{array}{l}\text { - Information } \\
\text { Management }\end{array}$ & $\begin{array}{l}\text { Distribution of business } \\
\text { model elements } \\
\text { of selected studies }\end{array}$ & & \\
\hline - Publisher & & & & \\
\hline
\end{tabular}

IV: First results $(n=403)$ and included studies after final screening $(n=31)$

\begin{tabular}{lcc}
\hline \multicolumn{1}{c}{ Search Keywords } & First results & lncluded studies after final screening \\
\hline Business Model lnnovation & 369 & 18 \\
Business Model Innovation + Approach & 18 & 7 \\
Business Model Innovation + Strategy & 7 & 4 \\
State of Business Model lnnovation & 0 & 0 \\
Business Model lnnovation Process & 7 & 1 \\
Phases of Business Model lnnovation & 2 & 1 \\
\hline IN TOTAL & 403 & 31 \\
\hline
\end{tabular}




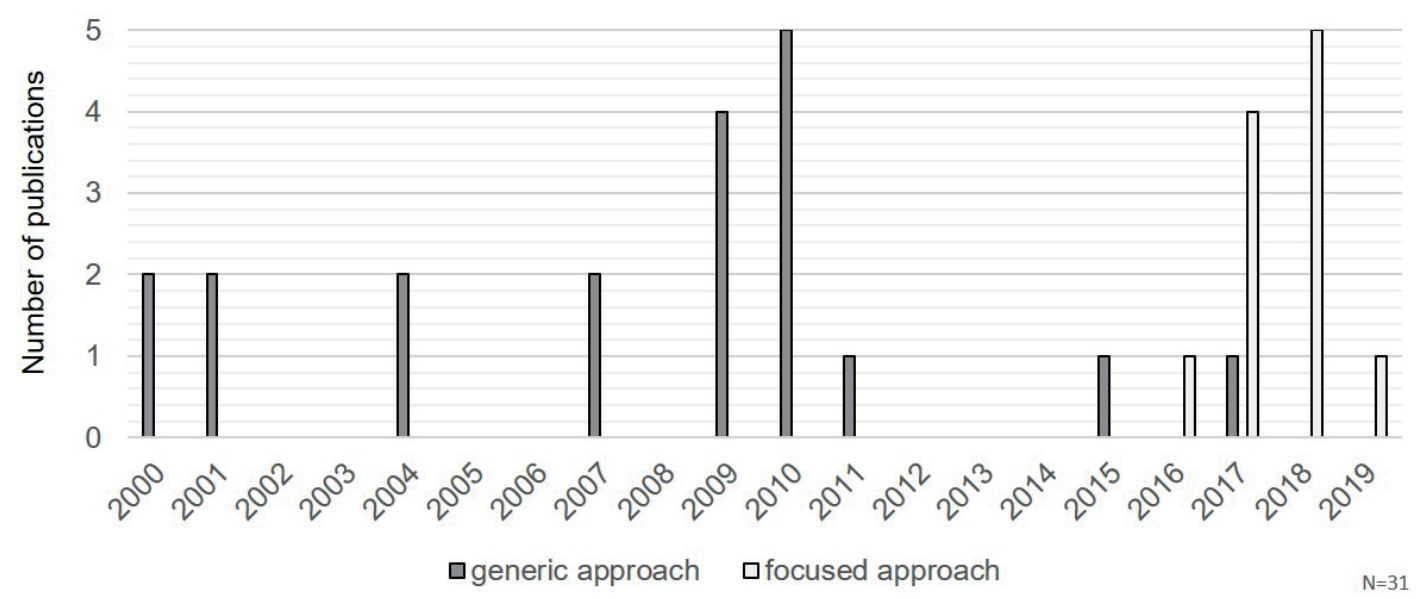

5: Publications of selected studies over time

the title which creates significantly lower the results to 369 articles. The research findings point out that there are about eight times less academic articles available focusing on business model innovation that on business models in general. This proves that the research maturity of business model innovation is less evolved than in business models based on the amount of published studies.

Further research with combination of "business model innovation" and keywords "approach" and "strategy" creates 25 additional results. The keyword "state of business model innovation" is not covered in any title, whereas "business model innovation process" leads to seven additional articles. However, the seven articles are reduced during the three screening phases down to one study. Moreover, two academic articles result by searching for "phases of business model innovation". Finally, after three screening steps, 31 studies are identified for further comparison (Tab. IV).

In general, the included 31 studies are published in the timeline between 2000 and 2019 (Fig. 5). In total, 20 of the investigated approaches are generic. The other eleven $(35 \%)$ studies focus on one of the topics business transformation, digitalization or sustainability. In addition, six (19\%) approaches are based on theories of previously academic authors. Eighteen (55\%) approaches are based on case studies or practical experiences of the authors. Twelve of the 31 academic studies (39\%) include interviews in their research.

The first studies are published in 2000 by Boulton et al. (2000) and Linder and Cantrell (2000). The study by Boulton (2000, p. 31) has a focus on the description of assets. A detailed description on what business model innovation is and how the process model is designed is neglected. The second study by Linder and Cantrell (2000, p. 6) represents the same level of detail. The authors disregard to go into detail about the elements of business models and the steps towards their development.
21 of 31 studies (67\%) are published between 2009-2011 and 2017-2019. The studies of 20092011 include the generic research of Grasl (2009, p. 141), Zott and Amid (2009, p. 5) and Osterwalder and Pigneur (2010, p.5). All three studies show a higher level of maturity and level of detail compared to the studies of the year 2000. Their approaches describe both the business model elements and the steps of the development of business models.

The studies of 2017-2019 also have a higher level of maturity in their business and process models and deal with one the specific topics of business transformation, digitalization or sustainability. However, six studies (19\%) focus on the development on sustainable business models, three approaches (10\%) deal with digital business model realization and two studies (6\%) focus on the transformation and change management from an existing business model to a new one.

Finally, the six studies (19\%) of Lindgarth et al. (2009, p. 2), Osterwalder and Pigneur (2010, p. 250), Weiner et al. (2010, p. 54), Wirtz (2010, p.193), Randles and Lasch (2016, pp.53-73) and Bocken et al. (2019, pp. 1498-1512) are the first approaches, which mention the importance of covering organizational mindset in their studies without going more into detail.

Tab. V summarizes the 31 evaluated studies. In accordance to the focus of the approaches they can be grouped into different areas of application. 23 (75\%) approaches focus on business strategy, five $(15 \%)$ on innovation strategy and three (10\%) on information management. The level of detail varies between a general overview to a detailed description of business model elements and process models. 20 theories (65\%) present a detailed description of business model elements whereas twelve studies (39\%) focus on a detailed approach for business model innovation itself. Moreover, eight approaches (26\%) include a detailed process model. Finally, generic approaches are mainly 
V: Overview of selected studies on business model innovation

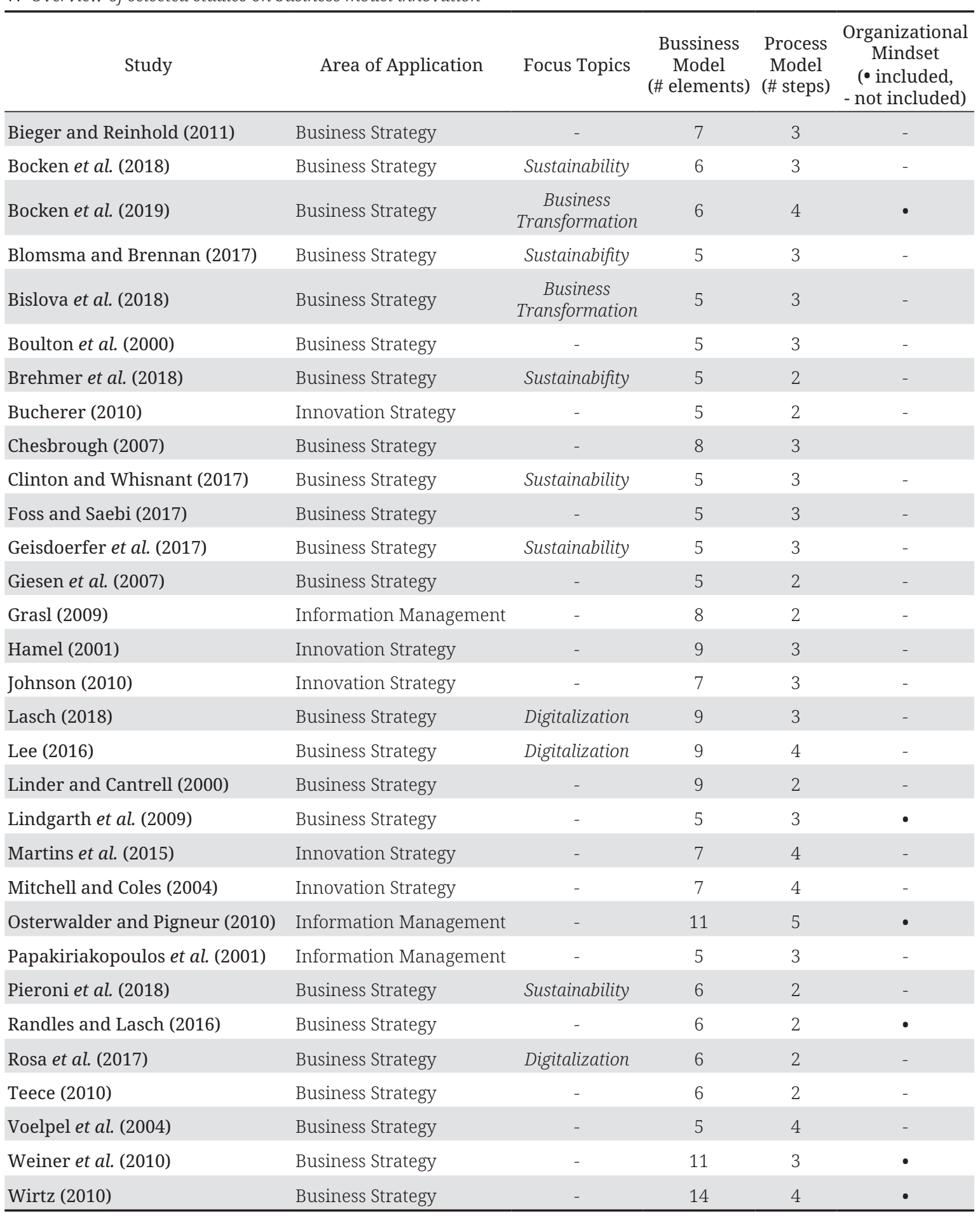

published until 2017. It is obvious that from 2016 onwards, the studies focus on a specific topic, such as business transformation, digitalization or sustainability. This seems to be in line with the overall market trends within the past decade.

\section{Qualitative Results of Studies ( $\mathrm{n}=31)$ \\ Most Common Business Model Elements Identified}

For identifying to which extend business model elements are addressed, all business model elements of the respective studies are analyzed (Tab. V). In the second step, the business model elements are 
clustered in accordance to the identified dimensions customer, value, value creation, partner and finance. In the final step, the original elements are mapped to thirteen common business model elements. Tab. VI outlines the identified five common dimensions with the derived thirteen common business model elements.

The analysis in Fig. 6 depicts that "customer" and "value proposition" are the most addressed business model elements with 30 namings followed by the elements "services", "key process" and "key resources" with 19 mentions. In contrast, the elements "partnership channels" and "partnership relations" are addressed six times in the selected studies.

In general, the analysis shows that "value" and "value creation" are the dominant dimensions of the common business model elements followed by the "customer dimension". This evidences a strong focus through all studies on value proposition and the interlinkage with the customer perspective. This analysis (Fig. 6) also demonstrates that the partner and financial dimensions are under-represented and not covered by the majority of investigated studies.

\section{Most Common Process Steps Identified}

To generate findings on the current research status on process steps, the process models of the selected 31 studies are also evaluated (Fig. 7). Reviewing the selected studies on business model innovation in general emphasizes that current research strongly focuses on identifying, describing and recommending a process that serves as a guideline for companies to innovate their business model.

At first, the steps of every process model are counted, analyzed and compared to the other studies. Tab. V gives an overview of the number of process steps per study. Secondly, the process steps are grouped to derive common process steps throughout all selected studies.

VI: Most common business model elements identified in selected studies

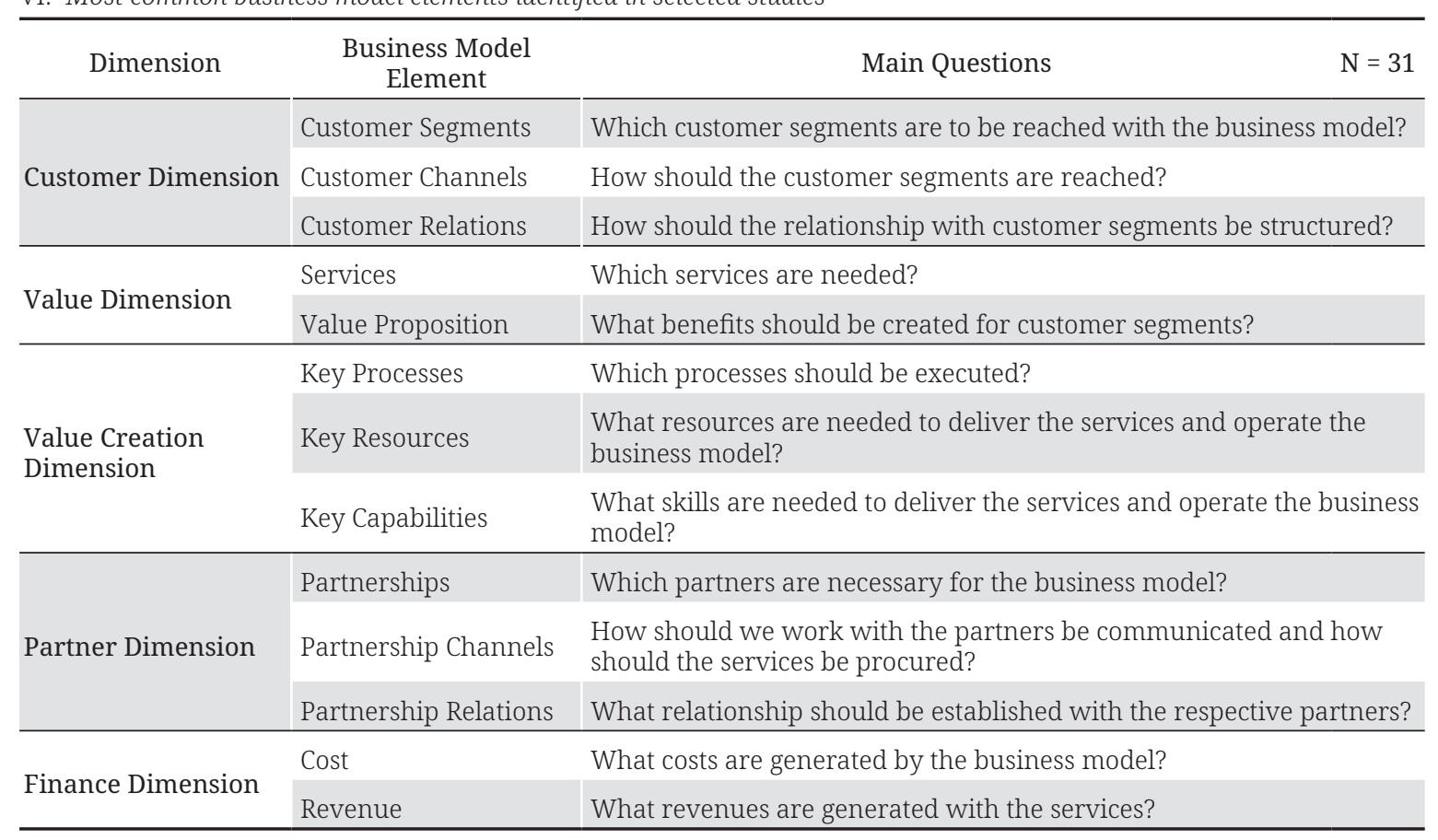

\begin{tabular}{|c|c|c|}
\hline & Customer Segments & 15 \\
\hline Customer Dimension & Customer Channels & 13 \\
\hline & Customer Relations & $\square 11$ \\
\hline & Services & 19 \\
\hline Value Dimension & Value Proposition & \\
\hline & Key Processes & 19 \\
\hline Value Creation Dimension & Key Ressources & 19 \\
\hline & Key Capabilities & 9 \\
\hline & Partnerships & 二 \\
\hline Partner Dimension & Partnership Channels & 6 \\
\hline & Partnership Relations & $\square 6$ \\
\hline Finance Dimension & Cost & $\square 5$ \\
\hline & Revenue & $\Longrightarrow$ \\
\hline
\end{tabular}

6: Amount of mentioned business model elements in selected studies 


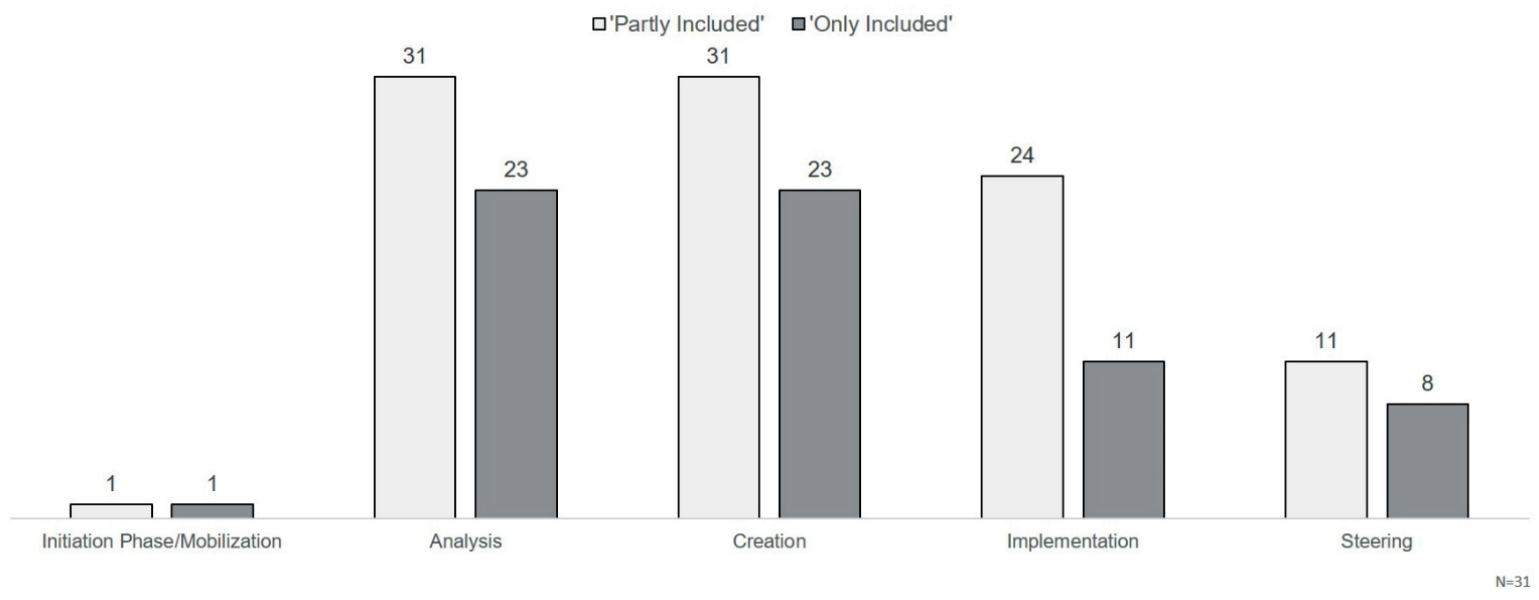

7: Considered process steps in selected studies Search Keywords First res ults

The findings identify that analysis, creation, implementation and steering are scientifically accepted steps (Fig. 7). The process steps analysis and creation are the only ones, which are partly included in all 31 studies. This reveals that research primarily concentrates on those two steps. 24studies (75\%) also mention the implementation step and eleven studies (35\%) contain a steering phase. The initiation/ mobilization step is only described by Osterwalder and Pigneur (3\%) (2010, p. 250).

\section{Organizational Mindset Addressed in Included Studies}

Despite the extensive research on process models, the role of organizational mindset is scarcely addressed. Instead, the authors focus on an abstract sequence of steps without considering the impact of the cognitive, behavioral, structural and cultural elements of an organization that form the dominant logic. Among the reviewed business model innovation processes, only Lindgarth et al. (2009, p. 2), Weiner et al. (2010, p. 54), Wirtz (2010, p. 193), Randles and Lasch (2016, pp. 53-73) and Bocken et al. (2019, pp.1498-1512) acknowledge organizational mindset as an innovation barrier. Moreover, Osterwalder and Pigneur (2010, p. 250) are the only researchers attempting to address it by implementing a step of mobilization into their process. Osterwalder and Pigneur (2010, pp. 249-251) advise organizations to mobilize and prepare for a successful business model innovation. By recognizing that the steps implementation and steering heavily depend on the outcome of the first three steps, they emphasize their significance. To execute the mobilization, they name creating awareness and motivation, assembling the right team, gaining appropriate information and establishing a common language to discuss business models, as crucial activities (Osterwalder and Pigneur, 2010, p. 250). They further emphasize the importance of top management engagement during this step, which includes educating them on the importance of the project beforehand (Osterwalder and Pigneur, 2010, p. 251). Nevertheless, the recommended mobilization is not considered sufficient to fully overcome the barriers of organizational mindset, since it is not explicitly addressed. Lindgardt et al. (2009, pp.6-7) also aim at mobilizing the organization by providing a set of strategic questions. This set only serves as a tool to assess the company's current business model and its environment to raise awareness on strengths, weaknesses and potential threats and opportunities. They do not include a method to mobilize an organization's established mindset.

\section{SUMMARY}

In summary, after three screening steps, 31 studies are identified for a detailed comparison. The approaches are published between 2000 and 2019, generic and not industry-specific. However, the ten studies published between 2009 and 2019 show a higher level of detail and maturity in the description of their business and process model.

Clustering the business models of the 31 studies, leads to a set of five common dimensions and thirteen common business model elements. The evaluation shows that the dominant dimensions of the common business model elements are value and value creation followed by the customer dimension. To generate findings on the current research status on process steps, the process models of the selected 31 studies are evaluated. The findings identify that analysis, creation, implementation and steering are scientifically accepted steps. The process steps analysis and creation are solely included in all 31 studies. This reveals that research primarily concentrates on those two steps. Thus, it is concluded that to innovate a business model, all common business model elements and process steps need to be covered by the respective approach.

Despite the extensive research on process models, the role of organizational mindset is only addressed by the following six approaches: Lindgarth et al. (2009, p. 2), Osterwalder and Pigneur (2010, p.250), 
Weiner et al. (2010, p. 54), Wirtz (2010, p. 193), Randles and Lasch (2016, pp. 53-73) and Bocken et al. (2019, pp.1498-1512). They acknowledge organizational mindset as an innovation barrier however do not give concrete advice how to overcome it.

It is recommended to conduct further research on the dominant organizational mindset within all four phases as well as concrete methods to overcome it.

\section{DISCUSSION}

The systematic literature review analyzes the current research status in the area of business model innovation. This extends previously published papers by Bieger and Reinhold (2011) as well as Boulton et al. (2000) which compare existing business model innovation approaches as a basis for their respective approach. The results of this paper exceed the previously mentioned studies above, since it generates a set on common business model elements as well as process steps. Moreover, the paper takes special attention on the analysis how organizational mindset is addressed in the included studies. At first, the research results create evidence that there is no common definition on the term business model innovation. Secondly, the evaluated 31 studies, as a result of three consecutive screening phases, aim at different business and process models based on their respective focus. The findings outline that the main generic studies are published in 2009-2011 whereas the majority of the specific studies are published in 2017-2019. Besides this, it is striking that from 2016 onwards, the academic approaches concentrate on a specific topic, such as digitalization or sustainability. One can assume that this is in line with the overall market trends within the past decade.

In general, the comparison of mentioned business model elements provide important findings. The analysis of business model elements highlights that "customer" and "value proposition" are the most addressed business model elements. This shows that value and value creation are the dominant dimensions of the common business model elements followed by the customer dimension. This generates evidences that all selected studies focus on value proposition and the interlinkage with the customer perspective.

In addition, during the analysis of the 31 process models it is evident that analysis, creation, implementation and steering are scientifically accepted steps. The focus on these two steps shows that research is primarily concentrated on them. In this context, a special perspective is on the addressing of organizational mindset in the selected 31 studies. An important finding is that among the reviewed business model innovation processes, only Lindgarth et al. (2009, p. 2); Weiner et al. (2010, p. 54); Wirtz (2010, p. 193); Randles and Lasch (2016, pp. 53-73) and Bocken et al. (2019, pp.1498-1512) acknowledge organizational mindset as an innovation barrier. Moreover, Osterwalder and Pigneur (2010, p. 250) are the only researchers addressing it by implementing a step of mobilization into the process. Nevertheless, the recommended mobilization is not considered sufficient to fully overcome the barriers of organizational mindset, since it is not explicitly addressed. Lindgardt et al. (2009, pp. 6-7) also aim at mobilizing the organization by providing a set of strategic questions. This set only serves as a tool to assess the company's current business model and its environment to raise awareness on strengths, weaknesses and potential threats and opportunities. They do not include a method to mobilize an organization's established mindset. In conclusion, the findings generate evidence that the role of organizational mindset is still scarcely covered in the selected studies on business model innovation. This finally demonstrates an evidence that the systematic integration of organizational mindset in business model innovation approaches is unrepresented and needs more attention in future research.

\section{CONCLUSION}

The main objective of the systematic literature review is to generate findings about the current research status of business model innovation with a special focus on organizational mindset. This is realized through an evaluation of 31 selected studies identified in a consecutive selection process of three phases. The selected studies are examined and evaluated in the dimensions of business model and process model in detail. The research creates evidence that all analyzed studies have a different focus and therefore vary in level of detail and content in the perspectives business and process model. Clustering the business models leads to a set of five common dimensions and thirteen common business model elements. The results show that all selected studies focus on value proposition and the interlinkage with the customer perspective. In addition, during the development of common process steps, it becomes evident that analysis, creation, implementation and steering are scientifically accepted steps.

An important finding is that overcoming the organizational mindset as a main barrier in business model innovation is not systematically integrated in any of the selected studies. 
In summary, the findings of this paper highlight that the current research in the field of business model innovation is not sufficient and further research has to follow concerning the following:

1. Business model innovation approaches are needed which cover the perspective business and process model in more detail.

2. Furthermore, business model innovation approaches with a focus on specific industries are not existing.

3. Finally, the overcoming of the dominant organizational mindset in business model innovation approaches needs to be systematically integrated in future studies.

\section{REFERENCES}

ANTHONY, S. D. 2012. Disruptive Innovation. Kodak and the Brutal Difficulty of Transformation. Harvard Business Review. [Online]. Available at: https://hbr.org/2012/01/kodak-and-the-brutaldifficult? [Accessed: 2018, July 16].

ANTHONY, S. D. 2016. Disruptive Innovation. Kodak's Downfall Wasn't About Technology. Harvard Business Review. [Online]. Available at: https://hbr.org/2016/07/kodaks-downfall-wasnt-abouttechnology [Accessed: 2018, July 16].

BENNETT, N. and LEMOINE, G. J. 2001. What VUCA Really Means for You. Harvard Business Review, 92(1-2): 1-7.

BENSINGER, G. 2017. Airbnb Valued at \$31 Billion After New Funding Round. The Wall Street Journal. [Online]. Available at: https://www.wsj.com/ articles/airbnb-valued-at-31-billion-after-newfundinground-1489086240 [Accessed: 2018, March 14].

BETTIS, R. A. 2000. The iron cage is emptying, the Dominant Logic no longer dominate. Advances in Strategic Management, 17: 167-174.

BETTIS, R. A. and PRAHALAD, C. K. 1995. The Dominant Logic: Retrospective and Extension. Strategic Management Journal, 16(1): 5-14.

BETTIS, R. A., WONG, Z. and BLETTNER, D. 2011. Handbook of Organizational Learning and Knowledge Management. $2^{\text {nd }}$ Edition. Chichester, United Kingdom: John Wiley and Sons.

BIEGER, T. and REINHOLD, S. 2011. The value-based business model [in German: Das wertbasierte Geschäftsmodell]. $1^{\text {st }}$ Edition. Berlin, Germany: Springer.

BILOSLAVO, R., BAGNOLI, C. and EDGAR, D. 2018. An eco-critical perspective on business models: The value triangle as an approach to closing the sustainability gap. Journal of Cleaner Production, 174: 746-762.

BLOMSMA, F. and BRENNAN, G. 2017. The Emergence of Circular Economy: A New Framing Around Prolonging Resource Productivity. Journal of Industrial Ecology, 21: 603-614.

BOCKEN, N., BOONS, F. and BALDASSARRE, B. 2019, Sustainable business model experimentation by understanding ecologies of business models. Journal of Cleaner Production, 208: 1498-1512.

BOCKEN, N. M. P., SCHUIT, C. S. C. and KRAAIJENHAGEN, C. 2018. Experimenting with a circular business model: Lessons from eight cases. Environmental Innovation and Societal Transitions, 28: 79-95.

BOUCHIKHI, H. and KIMBERLY, J. R. 2003. Escaping the Identity. MIT Sloan Management Review, 44(3): 20-26.

BOULTON, R., LIBERT, B. and SAMEK, S. 2000. A business model for the new economy. Journal of Business Strategy, 4: 29-35.

BUCHERER, E. 2010. Business Model Innovation: Guidelines for a Structured Approach. $1^{\text {st }}$ Edition. Aachen, Germany: Shaker.

CAVALCANTE, S. A., KESTING, P. and ULHOI, J. P. 2011. Business model dynamics and innovation: (Re-) establishing the missing linkages. Management Decisiony, 49(8): 1327-1342.

CHESBROUGH, H. 2007. Open business models: how to thrive in the new innovation landscape. $1^{\text {st }}$ Edition. Boston, MA: Harvard Business Press.

CLINTON, L. and WHISNANT, R. 2019. Business Model Innovations for Sustainability. In: Managing Sustainable Business. $1^{\text {st }}$ Edition. Berlin: Springer, pp. 463-503.

CSIK, M. 2014. Patterns and the generation of ideas for business model innovations [in German: Muster und das Generieren von Ideen für Geschäftsmodellinnovationen]. [Online]. Available at: https://www1. unisg.ch/www/edis.nsf/SysLkpByIdentifier/4263/protect|T1|textdollarFILE/dis4263.pdf [Accessed: 2018, October 18].

FOSS, N. J. and SAEBI, T. 2017. Fifteen years of research on business model innovation. Journal of Management, 43: 200-227.

FRANKE, T. and ZU KNYPHAUSEN-AUFSESS, D. 2014. On Dominant Logic: Review and Synthesis. Journal of Business Economics, 84(1): 27-70. 
GAVETTI, G. 2012. With psychology to new strategies [in German: Mit Psychologie zu neuen Strategien]. Harvard Business Manager, 34(1): 76-86.

GEISSDOERFER, M., SAVAGET, P. and EVANS, S. 2017. The Cambridge Business Model Innovation Process. Procedia Manuf, 8: 262-269.

GIESEN, E., BERMAN, S. J., BELL, R. et al. 2007. Three Ways to Successfully Innovate Your Business Model. Strategy \& Leadership, 35(6): 27-33.

GRASL, O. 2009. Professional Service Firms: Business Model Analysis - Methods and Case Studies. Doctoral dissertation. University of Stuttgart, Germany.

HACKLIN, F. and WALLNÖFER, M. 2012. The Business Model in the Practice of Strategic Decision Making: Insights from a Case Study. Management Decision, 50(2): 166-188.

HAMEL, G. 2001. Leading the Revolution. Strategy and Leadership, 29: 4-10.

HAWKINS, R. 2002. The Phantom of the Marketplace: Searching for New Ecommerce Business Models. Communications and Strategy, $2^{\text {nd }}$ quarter 2002 (46): 297-329.

HOLMES, F. 2017. Disrupt or Get Disrupted. Forbes. [Online]. Available at: https://www.forbes.com/ sites/greatspeculations/2017/03/07/disrupt-or-getdisrupted/ [Accessed: 2018, April 28].

JOHNSON, M. 2010. Seizing the white space: business model innovation for growth and renewal. $1^{\text {st }}$ Edition. Boston, MA: Harvard Business Press.

JOHNSON, M., CHRISTENSEN, C. and KAGERMANN, H. 2008. Reinventing Your Business Model. Harvard Business Review, 86(12): 50-59.

LAASCH, O. 2018. Beyond the purely commercial business model: Organizational value logics and the heterogeneity of sustainability business models. Long. Range Plan., 51: 158-183.

LEE, E. 2016. Service Design Challenge: Transitioning From Concept to Implementation. In: Service Design Geographies. Proceedings of the ServDes2016 Conference, pp. 228-240.

LINDER, J. and CANTRELL, S. 2000. Changing Business Models: Surveying the landscape. Munich, Germany: Accenture.

LINDGARDT, Z., REEVES, M., STALK, G. et al. 2009. Business Model Innovation: when the game gets tough change the game. Munich, Germany: The Boston Consulting Group.

MAGRETTA, J. 2002. Why Business Models Matter. Harvard Business Review. [Online]. Available at: https://hbr.org/2002/05/why-business-models-matter [Accessed: 2018, July 16].

MARTINS, L., RINDOVA, V. and GREENBAUM, B. 2015. Unlocking the Hidden Value of Concepts: A Cognitive Approach to Business Model Innovation. Strategic Entrepreneurship Journal, 9: 99-117.

MASON, K. and SPRING, M. 2011. The sites and practices of business models. Industrial Marketing Management, 40(6): 1032-1041.

MATZLER, K., BAILOM, F., VON DEN EICHEN, F. et al. 2016. Digital Disruption. How to prepare your company for the digital age [in German: Digital Disruption. Wie Sie Ihr Unternehmen auf das digitale Zeitalter vorbereiten]. Munich, Germany: Vahlen.

MITCHEL, D. and COLES, C. 2003. The ultimate competitive advantage of continuing business model innovation. Journal of Business Strategy, 24: 15-21.

MITCHEL, D. and COLES, C. 2004. Business model innovation breakthrough moves. Journal of Business Strategy, 25: 16-26.

NAUGHTON, C. and BAECKER, D. 2016. Digital Enlightenment - Six Digital Mindsets [in German: Digitale Erleuchtung - Sechs Digitale Mindsets]. [Online]. Available at: https://www.zukunftsinstitut. de/fileadmin/user_upload/DigitaleErleuchtung_Von_Verblendung_zu_Erkenntnis.pdf [Accessed: 2018, June 28].

ORDUNA-MALEA, E., AYLLÓN, J. M., MARTÍN-MARTÍN, A. et al. 2015. Methods for estimating the size of Google Scholar. Scientometrics, 104: 931-949.

OSTERWALDER, A. and PIGNEUR, Y. 2010. Business Model Generation. New Jersey, NJ: John Wiley and Sons.

PAPAKIRIAKOPOULOS, D., POYLUMENAKOU, A. and DOUKIDIS, G. 2001. Building e-Business Models: An Analytical Framework and Development Guidelines. In: $14^{\text {th }}$ Bled Electronic Commerce Conference. Bled, Slovenia, 25-26 June, pp. 446-464.

PIERONI, M., PIGOSSO, D. and MCALOONE, T. 2018. Exploring the synergistic relationships of circular business model development and product design. In: $15^{\text {th }}$ International Design Conference - Design 2018. pp. 2715-2726.

PORTER, M. E. 1985. The Competitive Advantage: Creating and Sustaining Superior Performance. New York, NY: Free Press.

RANDLES, S. and LAASCH, O. 2016. Theorising the normative business model. Organisational Environment, 29: 53-73.

RAPPA, M. 2004. The utility business model and the future of computing services. IBM Systems Journal, 1(43): 32-42. 
ROGERS, D. L. 2016. The digital transformation playbook. Rethink your business for the digital age. New York, NY: Columbia University Press.

ROSA, M., MARQUES, C. A. N. and ROZENFELD, H. 2017. Commonalities and particularities of pss design process and design thinking. Procedia CIRP, 64: 253-258.

SCHALLMO, D. 2013. Business model innovation. Basics, existing approaches, methodical procedure and B2B business models [in German: Geschäftsmodell-Innovation. Grundlagen, Bestehende Ansätze, Methodisches Vorgehen und B2B Geschäftsmodelle]. $1^{\text {st }}$ Edition. Wiesbaden, Germany: Springer Gabler.

SCHNEIDER, S. and SPIETH, P. 2013. Business Model Innovation: Towards an Integrated Future Research Agenda. International Journal of Innovation Management, 17(1): 1-34.

SCHULDT, C. 2016. From delusion to enlightenment. An excerpt from the introduction to the New Study "Digital Enlightenment” [in German: Von Verblendung zu Erleuchtung. Ein Auszug aus der Einleitung zur Neuen Studie "Digitale Erleuchtung”]. ZukunftInstitut. [Online]. Available at: https:// www.zukunftsinstitut.de/artikel/digitalisierung/von-verblendung-zu-erleuchtung/ [Accessed: 2018, June 28].

SHERMAN, L. 2017. How MIT Dragged Uber Through Public Relations Hell. Forbes. [Online]. Available at: https:/www.forbes.com/sites/lensherman/ 2018/03/07/how-mit-dragged-uber-through-publicrelations-hell [Accessed: 2018, April 18].

SKARZYNSKI, P. and GIBSON, R. 2008. Innovation to the core: a blueprint for transforming the way your company. Boston, MA: Harvard Business Press.

SNIUKAS, M., PARKER, L. and MORASKY, M. 2016. The Art of Opportunity. $1^{\text {st }}$ Edition. Hoboken, NJ: John Wiley and Sons.

STEENKAMP, C. and VAN DER WALT, A. 2004. Web phenomenon applied as ICT platform in support of business model innovation. South African Journal of Information Management, 6(1): a295.

TEECE, D. 2010. Business Models, Business Strategy and Innovation. Long Range Planning, 43: 172-194.

TIKKANEN, H., LAMBERG, J.-A., PARVINEN, P. et al. 2005. Managerial cognition, action and the business model of the firm. Management Decision, 43(6): 789-809.

TOVSTIGA, G. and BIRCHALL, D. W. 2014. Capturing Opportunity in Disruption: Strategic Capabilties and Organization Factors. [Online]. Available at: https://warwick.ac.uk/fac/soc/wbs/conf/olkc/archive/ oklc5/papers/a-3_tovstiga.pdf [Accessed: 2018, October 18].

TRIPSAS, M. and GAVETTI, G. 2000. Capabilities, cognition, and inertia: evidence from digital imaging. Strategic Management Journal, 21(10/11): 1147-1161.

VOELPEL, S., LEIBOLD, M. and EDEN, B. 2004. The wheel of business model reinvention: how to reshape your business model to leapfrog competitors. Journal of Change Management, 3: 259-276.

WEINER, N., RENNER, T. and KETT, H. 2010. Business models in the Internet of Services; current status in research and practice [in German: Geschäftsmodelle im Internet der Dienste; Aktueller Stand in Forschung und Praxis]. Stuttgart, Germany: Frauenhofer Institut für Arbeitswirtschaft und Organisation IAO.

WIRTZ, B. 2010. Business Model Management. $1^{\text {st }}$ Edition. Wiesbaden, Germany: Gabler.

WÖRDENWEBER, B., EGGERT, M. and SCHMITT, M. 2012. Behaviour-oriented innovation management. Activate entrepreneurial potential [in German: Verhaltensorientiertes Innovationsmanagement. Unternehmerisches Potenzial Aktivieren]. $1^{\text {st }}$ Edition. Heidelberg, Germany: Springer.

ZERVAS, G., PROSERPIO, D. and BYERS, J. W. 2016. The Rise of the Sharing Economy: Estimating the Impact of Airbnb on the Hotel Industry. [Online]. Available at: http://people.bu.edu/zg/publications/ airbnb.pdf [Accessed: 2018, March 18].

ZOTT, C. and AMIT, R. 2009. Business Model Design: An Activity System Perspective. Long Range Planning, 43(2-3): 216-226. 


\title{
CORRIGENDA
}

\author{
of the article \\ LANG MICHAEL. 2020. Business Model Innovation Approaches: A Systematic Literature Review. Acta Universitatis \\ Agriculturae et Silviculturae Mendelianae Brunensis, 68(2): 435-449. https://doi.org/10.11118/actaun202068020435
}

Link to this article: https://doi.org/10.11118/actaun202068050901

Author unproperly cited some parts of his article. Proper citations are:

Page 436 - right column, line 16

printed as: "At the moment, there is no commonly accepted definition for the term business model (Johnson et al., 2008, p. 60)."

corrected to: "In reference to Schallmo (2013, p. 21-22) "at the moment, there is no commonly accepted definition for the term business model (Johnson et al., 2008, p. 60)."

Page 437 - Fig. 1

printed as: "1: Characteristics of business model definitions"

corrected to: "1: Characteristics of business model definitions (Schallmo, 2013, p. 22)"

Page 437 - left column, line 30

printed as: "No common definition for the term business model innovation is present"

corrected to: "In reference to Schallmo (2013, p. 27) no common definition for the term business model innovation is present."

Page $444-T a b . V I$

printed as: "VI: Most common business model elements identified in selected studies"

corrected to: "VI: Schallmo's business model dimensions and elements used for analyzing the identified studies (Schallmo 2013, p. 23, p. 118-119)"

Page $444-$ Fig. 6

printed as: "6: Amount of mentioned business model elements in selected studies"

corrected to: "6: Amount of mentioned business model elements in selected studies in reference to Schallmo's business model dimensions and elements (Schallmo, 2013, p. 23, p. 118-119)" 